\section{Sol-gel synthesis and structural characterization of Fe doped barium titanate nanoceramics}

\author{
Mohammed TIHTIH - Institute of Ceramics and Polymer Engineering, \\ University of Miskolc, Hungary • medtihtih@gmail.com \\ KARoum LIMAME - Laboratoire de Physique Théorique et Appliquée, \\ Morocco $\cdot$ klimame1974@yahoo.com \\ YaHYA ABABOU - Laboratoire de Physique Théorique et Appliquée, \\ Morocco - Ababou.yahya0@hotmail.com
}

SALAHEdDINE SAYOURI - Laboratoire de Physique Théorique et Appliquée, Morocco - s.sayouri12@gmail.com

JAMAL-ELDIN F. M. IBRAHIM - Institute of Ceramics and Polymer Engineering, University of Miskolc, Hungary - jamalfadoul@gmail.com

Érkezett: 2019. 11. 29. - Received: 29. 11. 2019. - https://doi.org/10.14382/epitoanyag-jsbcm.2019.33

\begin{abstract}
Fe-doped barium titanate $\left(\mathrm{BFe}_{\mathrm{x}} \mathrm{T}\right)$ nanoceramics were successfully prepared by a simple sol-ge process, these materials are very interesting and could be a candidate for many optoelectronic applications. X-ray diffraction (XRD) patterns of the obtained samples, heat-treated at a quite low temperature $\left(800^{\circ} \mathrm{C} / 3 \mathrm{~h}\right)$ revealed that $\mathrm{BFe}_{\mathrm{x}} \mathrm{T}$ nanoceramics crystallized into a tetragonal phase perovskite structure. The occupation of the $\mathrm{Ba}$ and $\mathrm{Ti}$ sites by $\mathrm{Fe}$ in the $\mathrm{BaTiO}_{3}$ lattice and the evolution of the different parameters (crystallite size, lattice parameters and strain) as functions of the Fe doping have been discussed in details using several characterization techniques including XRD and Fourier Transformation Infrared (FT-IR).

Keywords: Sol-gel, Barium titanate nanoceramics, Fe-doped barium titanate nanoceramics, X-ray Diffraction

Kulcsszavak: Szol-gél, bárium-titanát, nanokerámia, Fe-adalékolt bárium-titanát, röntgendiffrakció
\end{abstract}

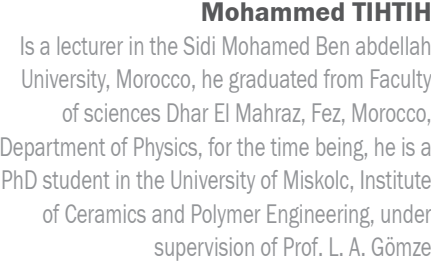

Karoum LIMAME

Lecturer and Researcher, research interests: Synthesis and Processing of Ceramics and Compounds, Materials Characterization and Simulation for the teaching of physics

Work Experience: Titular Researcher, at "Sid Mohamed Ben Abdellah University" publications in JCR Journals in the field of Ceramics Materials and Composites.

Yahya ABABOU is establisher and professor of the Department of physics in the Faculty of Sciences Dhar El mahraz Sidi Mohamed Ben Abdellah University, Morocco.

Salaheddine SAYOURI is professor and Head of Laboratory of Theoretical and Applied Physics, Department of Physics, Sidi Mohamed Ben Abdellah University. Author and co-author of 4 patents and more than 90 scientific articles indexed Scopus.

Jamal-EIdin F. M. IBRAHIM is a lecturer in the University of Bahri, Khartoum Sudan, he graduated from University of Marmara, Istanbul, Turkey, Institute of Pure and Applied Sciences, Department of Metallurgical and Materials Engineering, for the time being, he is a $\mathrm{PhD}$ student in the University of Miskolc, Institute of Ceramics and Polymer Engineering, under supervision of Prof. L. A. Gömze

\section{Introduction}

The popularity of the research in the area of the high-tech ceramics is largely grown lately [1-31], since the discovery of the ferroelectricity phenomenon, barium titanate $\mathrm{BaTiO}_{3}(\mathrm{BT})$ has been a fundamental member of the ferroelectric perovskite family. This compound has been used for a long time in many industrial sectors including full swing multilayer ceramic capacitors (MLCCs) [32], the realization of the ferroelectric random access memories (FRAMs) [33], thermistors manufacturing [34] and detection of polluting gases such as $\mathrm{CO}$ [35]. However, multilayer capacitors have long been at the forefront of $\mathrm{BaTiO}_{3}$ applications. The $\mathrm{BaTiO}_{3}$ nanoceramics can be synthesized by various methods such as solid-state reaction [36], hydrothermal synthesis [37], sol-gel [38] and co-precipitation method [39], compared to other methods, solgel is considered as a simple and easy method which can allows production of a high purity $\mathrm{BaTiO}_{3}$ with very fine particles of controllable size, moreover, it is possible to easily modify the physical properties of $\mathrm{BT}$ since these are very sensitive to doping on the A-site $\left(\mathrm{Ba}_{\mathrm{D}} \mathrm{TiO}_{3}\right), \mathrm{B}$-site $\left(\mathrm{BaTi}_{\mathrm{D}} \mathrm{O}_{3}\right)$ and substitution on both sites (co-doping) $\mathrm{Ba}_{\mathrm{D}} \mathrm{Ti}_{\mathrm{D}} \mathrm{O}_{3}$ which mainly depends on their ionic radii [40]. Recently, the doping of $\mathrm{BaTiO}_{3}$ nanoceramics by $3 \mathrm{~d}$ transition metals ( $\mathrm{Fe}, \mathrm{Co}, \mathrm{Mn}, \mathrm{Ni}$...) have attracted much attention, 3d transition elements are more likely to be considered as dopants due to their electric and high magnetic properties. To date, a number of research works have reported the effect of the $3 \mathrm{~d}$ transition metals on the structural and physicochemical properties of $\mathrm{BaTiO}_{3}$ nanoceramics. Rani et al [41] have studied the effect of Fe doping on structural, magnetic and magnetoelectric properties of $\mathrm{BaTiO}_{3}$ prepared via solid-state reaction route. Khirade et al [42] have reported the effect of Fe doping on the structural, optical and electrical properties of $\mathrm{BaTiO}_{3}$ nanoceramics synthesis by sol-gel process. Maikhuri et al [43] have demonstrated the influence of A- and B-site substitution on the structural and magnetic properties of $\mathrm{BaTiO}_{3}$. In the present work, $\mathrm{Fe}$ doped $\mathrm{BaTiO}_{3}$ nanoceramics have been prepared using sol-gel method, the prepared samples were characterized using X-Ray Diffraction and FT-IR. The analysis of X-ray patterns was used to calculate the crystallite size, lattice parameters and lattice strain. The aim of this investigation is to study the effect of Fe dopant on the structural properties of $\mathrm{BaTiO}_{3}$, In particular, the occupation of $\mathrm{Ba}$ and/or Ti sites by $\mathrm{Fe}$ in the $\mathrm{BaTiO}_{3}$ structure.

\section{Method of elaboration}

Pure and $\mathrm{Fe}$-doped $\mathrm{BaTiO}_{3}$ were synthesized using sol-gel method, barium acetate trihydrate $\left(\mathrm{Ba}\left(\mathrm{CH}_{3} \mathrm{CO}_{2}\right)_{2} \cdot 3 \mathrm{H}_{2} \mathrm{O}\right)$, Iron acetate $\mathrm{Fe}\left(\mathrm{C}_{2} \mathrm{H}_{3} \mathrm{O}_{2}\right)_{2}$ and titanium alkoxide $\mathrm{Ti}\left[\mathrm{OCH}\left(\mathrm{CH}_{3}\right)_{2}\right]_{4}$ were used as precursors, lactic acid $\left(\mathrm{CH}_{3} \mathrm{CH}(\mathrm{OH}) \mathrm{COOH}\right)$ was used as peptizing agent, acetic acid was added to dissolve Iron acetate, and distilled water as solvent. As shown in Fig. 1, the first step is to prepare a colloidal solution of $\mathrm{TiO}_{2}$, to do this; the 
titanium alkoxide was added to an aqueous solution of lactic acid and $\mathrm{H}_{2} \mathrm{O}$ with continuous stirring at $70{ }^{\circ} \mathrm{C}$. After 24 hours of reaction, the white precipitate obtained is changed into a clear homogeneous solution. In a second step, the colloidal solution produced was added in stoichiometric quantities to iron and barium acetates. The obtained transparent sol was converted to a translucent gel after stirring at $90{ }^{\circ} \mathrm{C}$. Fine powders were prepared from the gel after drying at $90{ }^{\circ} \mathrm{C}$ and grinding. Finally, the nanopowders produced were calcined in air at a temperature of $800{ }^{\circ} \mathrm{C}$ for $3 \mathrm{~h}$ in a programmable oven. Phase identification of the prepared BFexT was performed using X-ray diffraction (Cu Ka radiation, $\lambda=1.5405980 \AA$ ) and Fourier transform infrared.

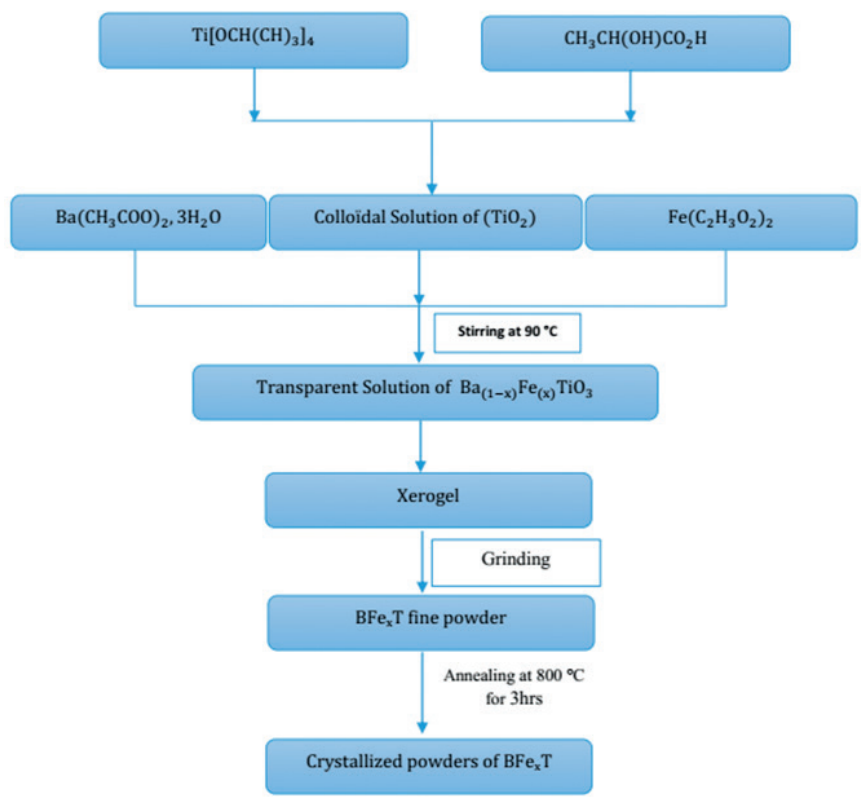

Fig. 1 Flow chart of the preparation of Fe doped $\mathrm{BaTiO}_{3}$ nanoceramics by sol-gel process

1. ábra A Fe-adalékolt $\mathrm{BaTiO}_{3}$ nanokerámia szol-gél eljárással történő elóállitásának folyamatábrája

\section{Results and discussion}

\subsection{Structural studies}

Fig. 2 shows the X-ray diffraction patterns of $\mathrm{Ba}_{1-\mathrm{x}} \mathrm{Fe}_{\mathrm{x}} \mathrm{TiO}_{3}(\mathrm{x}$ $=0,1,3 \%)$ samples prepared via sol-gel method. XRD patterns of pure and $\mathrm{Fe}$-doped $\mathrm{BaTiO}_{3}$ show a single tetragonal phase without any evidence of secondary phases. The XRD pattern of the samples can be indexed to the tetragonal perovskite structure with $\mathrm{P} 4 \mathrm{~mm}$ space group, which is in great concurrence with JCPDS No. 05-0626. An important fact revealed in Fig. 2 is that the peak of (101) of $\mathrm{Ba}_{1-\mathrm{x}} \mathrm{Fe}_{\mathrm{x}} \mathrm{TiO}_{3}(\mathrm{x}=0.01)$ is shifted to higher $2 \theta$ angle compared to the pure $\mathrm{BaTiO}_{3}$, while the peak of (101) of $\mathrm{Ba}_{1-\mathrm{x}} \mathrm{Fe}_{\mathrm{x}} \mathrm{TiO}_{3}(\mathrm{x}=0.03)$ is shifted to lower $2 \theta$ angle. The Peaks shifted to lower and higher angles indicate an increase and decrease in volume (V) of the unit cell respectively as shown in Table 1. $\mathrm{Fe}^{2+}$ has a smaller ionic radius (0.78 $\AA$ ) compared to that of $\mathrm{Ba}^{2+}(1.35 \AA$ Á). The slight shift of the peak positions in $\mathrm{BFe} 1 \mathrm{~T}$ with respect to $\mathrm{BaTiO}_{3}$ is may be attributed to the $\mathrm{Fe}^{2+}$ ionic size difference, which could eventually replace the $\mathrm{Ba}^{2+}$ ions in the $\mathrm{BaTiO}_{3}$ lattice [40] and leads to a reduction in the volume of the unit cell. In addition, the lower angle shift in the peaks of BFe3T can be assigned to the substitution of $\mathrm{Fe}^{2+}$ ion by $\mathrm{Ba}^{2+}$ and $\mathrm{Ti}^{4+}$ ions, but with a predominance of the $\mathrm{Ti}$ site occupancy in the $\mathrm{BaTiO}_{3}$ lattice. In contrary, and because of the reason that the $\mathrm{Fe}^{2+}$ ionic radii is larger compared to $\mathrm{Ti}^{4+}(0.605 \AA)$, it can be observed that the substitution of $\mathrm{Ti}-$ sites by $\mathrm{Fe}^{2+}$ create oxygen vacancies to neutralize the charge. Therefore, an increase in the unit cell volume is predicted as the unit cell parameters a and $c$ have increased.

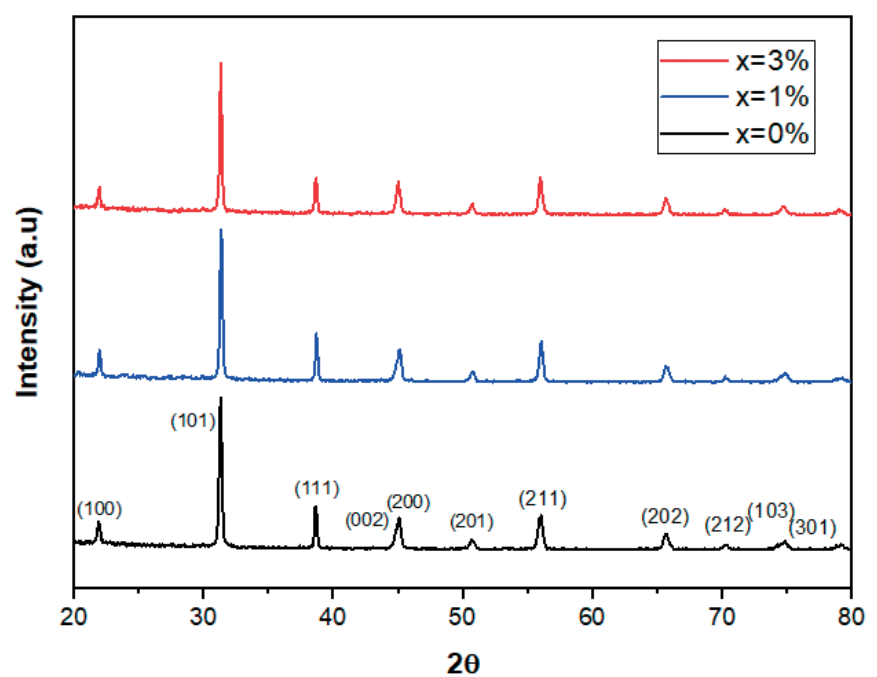

Fig. 2 X-ray diffraction patterns of prepared Fe-doped barium titanate nanoceramics

2. ábra Az elkészített Fe-adalékolt bárium-titanát nanokerámiák röntgendiffraktogramja

The crystallite size of the pure and $\mathrm{Fe}$-doped $\mathrm{BaTiO}_{3}$ was calculated from the X-ray diffraction patterns according to (101) peak using Debye-Scherrer formula [44]:

$D=\frac{0.9 \lambda}{\beta \cos \theta}$

Where $\mathrm{D}$ is the crystallite size, $\lambda$ is $\mathrm{X}$-ray wavelength, $\theta$ is the diffraction angle and $\beta$ is full width at half maximum (FWHM) of the (101) peak. The average crystallite size was calculated by settling the highest intensity peak. As listed in Table 1.

Moreover, the lattice strain $(\varepsilon)$ of all samples was estimated using the following equation [45]:

$\varepsilon=\frac{\beta}{4 \tan \theta}$

The estimated lattice parameters a and c, unit cell volume (V), position of the peak (101), lattice strain and crystallite size are listed in Table 1. It was found that the average crystallite size (D) increased with Fe concentration $x$. However, the lattice constant (c) and lattice strain have been decreased after doping. The increase in crystallite size is due to the big difference between the ionic radius of $\mathrm{Fe}^{2+}, \mathrm{Ba}^{2+}$ and $\mathrm{Ti}^{4+}[31$, 42]. The shift in the position of (101) in the XRD patterns and the change in the volume of unit cell after doping reveal that $\mathrm{Fe}$ is totally soluble into $\mathrm{BaTiO}_{3}$ lattice. 


\subsection{FT-IR analysis}

The Fourier transform infrared spectroscopy (FT-IR) spectrums of $\mathrm{BaFe}_{\mathrm{x}} \mathrm{TiO}_{3}(\mathrm{x}=0,1,3 \%)$ are shown in Fig. 3. The corresponding spectra show absorption bands in the wave number ranging from $4000-450 \mathrm{~cm}^{-1}$. The presence of a prominent peak at about $500 \mathrm{~cm}^{-1}$ in the pure $\mathrm{BaTiO}_{3}$ spectrum corresponds to the vibration of $\mathrm{Ti}-\mathrm{O}$ bond in the crystal lattice [46]. All the samples show a fingerprint of Ti-O and $\mathrm{Ti}-\mathrm{O}-\mathrm{Ti}$ bonds between $500 \mathrm{~cm}^{-1}$ and $750 \mathrm{~cm}^{-1}$ which is a molecular fingerprint of $\mathrm{BaTiO}_{3}$. The wavenumber of the absorption peak of Ti-O bond increases after doping, the peak is shifted from $481.12 \mathrm{~cm}^{-1}$ in pure $\mathrm{BaTiO}_{3}$ to $491.23 \mathrm{~cm}^{-1}$ in $3 \% \mathrm{Fe}$ doped $\mathrm{BaTiO}_{3}$ which indicates the change of the unit cell size. Moreover, the bands observed in the region from $1425 \mathrm{~cm}^{-1}$ to $1449 \mathrm{~cm}^{-1}$ could be attributed to $\mathrm{BaCO}_{3}$ phase present in the prepared samples [47].

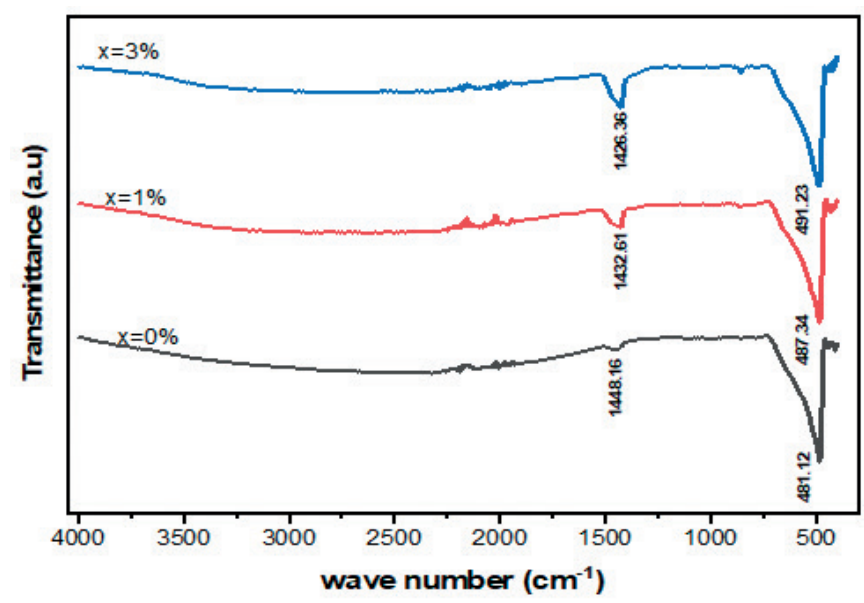

Fig. 3 FT-IR spectrums of pure and Fe-doped barium titanate at different Concentrations ( $x=0,0.01$ and 0.03 )

3. ábra A tiszta és a Fe-adalékolt bárium-titanát FT-IR spektrumai különbözó koncentráció esetén ( $x=0 ; 0,01$ és 0,03 )

\begin{tabular}{lccccccc}
\multicolumn{1}{|c}{$\mathbf{x}$} & $\mathbf{a}(\AA)$ & $\mathbf{c}(\AA)$ & $\mathbf{V}\left(\AA^{3}\right)$ & $\begin{array}{c}\text { Position } \\
\text { 20 of } \\
(\mathbf{1 0 1})\end{array}$ & $\begin{array}{c}\text { Crystallite } \\
\text { size }(\mathrm{nm})\end{array}$ & $\begin{array}{c}\text { Lattice } \\
\text { strain }\end{array}$ \\
\hline $\mathbf{0}$ & 3.9943 & 4.0191 & 64.12245 & 31.31533 & 34.56 & 0.003883 \\
\hline $\mathbf{0 . 0 1}$ & 3.9949 & 4.0164 & 64.01643 & 31.36792 & 36.38 & 0.003584 \\
\hline $\mathbf{0 . 0 3}$ & 4.0013 & 4.0167 & 64.30898 & 31.33112 & 42.46 & 0.003159
\end{tabular}

Table 1 The position of the peak (101), lattice parameters, Volume of the unit cell, lattice strain and crystallite size of $\mathrm{BaFe}_{x} \mathrm{TiO}_{3}(x=0,1$ and $3 \%)$ nanoceramics 1. táblázat A csúcs helyzete (101), a rácsparaméterek, az egységcellák térfogata, a rácsos törzs és a $\mathrm{BaFe} \mathrm{TiO}_{3}(x=0 ; 1$ és 3\%) nanokerámia kristálymérete

\section{Conclusion}

To summarize, pure and Fe doped barium titanate nanoceramics were synthesized using sol-gel method, the obtained powders were calcined at $800{ }^{\circ} \mathrm{C}$ for $3 \mathrm{~h}$, the calcined samples were characterized using XRD and FT-IR spectroscopy. The XRD results confirm the presence of single tetragonal phase for both pure and Fe doped materials. This measurement reveals that the $\mathrm{Fe}^{2+}$ ion may replace $\mathrm{Ba}^{2+}$ for $\mathrm{x}=1 \%$ or the both $\mathrm{Ba}^{2+}$ and $\mathrm{Ti}^{4+}$ but with a predominance for the Ti-site in the case of $x=3 \%$. FT-IR measurements showed that the elaborated samples have perovskite structure, which is in a good agreement with XRD results. The modification in the structural properties after doping indicates that Fe has successfully doped into $\mathrm{BaTiO}_{3}$ lattice.

\section{Acknowledgements}

Thanks to the University of Miskolc (Hungary), University Sidi Mohamed Ben Abdellah USMBA (Morocco) to support this work.

\section{References}

[1] Emese Kurovics et al (2019): Effect of composition and heat treatment on porosity and microstructures of technical ceramics made from kaolin and IG-017 additive, IOP Conf. Ser.: Mater. Sci. Eng.vol. 613012025 https://doi.org/10.1088/1757-899X/613/1/012025

[3] J. F. M. Ibrahim et al (2019): The Influence of Cr doping on the Structural and Magnetic Properties of HoMnO3 Multiferroic Ceramics, IOP Conf. Ser.: Mater. Sci. Eng. Vol. 613012009 https://doi.org/10.1088/1757-899X/613/1/012009

[3] Gömze, László A. - Ludmila N. Gömze (2003): Építőanyag-JSBCM vol. 55 no. 4 pp. 133-140 http://dx.doi.org/10.14382/epitoanyag-jsbcm.2003.23

[4] Gömze, L. A. - Gömze, L. N. (2013): Ceramic based lightweight composites with extremedynamicstrength,IOPConf.Ser.: Mater.Sci.Eng. Vol.47012033 https://doi.org/10.1088/1757-899X/47/1/012033

[5] Gömze, L. A., 2016: Applied materials science I. Compilation of Selected Scientific Papers, pp.1-189.

[6] Gömze, L. A. - Gömze, L. N. (2011): "Hetero-modulus alumina matrix nanoceramics and CMCs with extreme dynamic strength" IOP Conf. Ser.: Mater. Sci. Eng. Vol. 18082001 http://dx.doi.org/10.1088/1757-899X/18/8/082001

[7] Gömze, L. A. - Gömze, L. N. (2017): Rheological principles of development hetero-modulus and hetero-viscous complex materials with extreme dynamic strength, IOP Conf. Ser.: Mater. Sci. Eng. Vol. 175012001 http://dx.doi.org/10.1088/1757-899X/175/1/012001

[8] Gömze, L. A. - Gömze, L. N. (2010): Mechanical stress relaxation in hetero-modulus, hetero-viscous complex ceramic materials, Építőanyag-JSBCM vol. 62 no. 4 p. 98 http://dx.doi.org/10.14382/epitoanyag-jsbcm.2010.18

[9] E. Kurovics et al (2017): Development ceramic composites based on $\mathrm{Al}_{2} \mathrm{O}_{3}, \mathrm{SiO}_{2}$ and IG-017 additive, IOP Conf. Ser.: Mater. Sci. Eng. Vol. 175 012013 https://doi.org/10.1088/1757-899X/175/1/012013

[10] Gömze, L. A. - Gömze, L. N. (2009): Alumina-based hetero-modulus ceramic composites with extreme dynamic strength - phase transformation of Si3N4 during high speed collisions with metallic bodies, ÉpítőanyagJSBCM vol. 61 no. 2 p. 38 http://dx.doi.org/10.14382/epitoanyag-jsbcm.2009.7

[11] Kulkov, S. N. - Savchenko, N. L. (2008): Wear behavior of zirconia-bazed ceramics under high-speed dry sliding on steel, Építőanyag-JSBCM vol. 60 no. 3 pp. 62-65. http://dx.doi.org/10.14382/epitoanyag-jsbcm.2008.10

[12] J. F. M. Ibrahim et al (2019): The influence of composition, microstructure and firing temperature on the density, porosity, and shrinkage of new zeolite-alumina composite material, Építőanyag-JSBCM vol. 71 no. 4 p. 120 https://doi.org/10.14382/epitoanyag-jsbcm.2019.21

[13] O. B. Kotova, et al (2019): Composite materials based on zeolitemontmorillonite rocks and aluminosilicate wastes, Építőanyag-JSBCM vol. 71 no. 4 p. 125 https://doi.org/10.14382/epitoanyag-jsbcm.2019.22

[14] E. Kurovics, et al (2019): Composite materials based on zeolitemontmorillonite rocks and aluminosilicate wastes, Építőanyag-JSBCM vol. 71 no. 4 p. 114 https://doi.org/10.14382/epitoanyag-jsbcm.2019.20

[15] T. Shchemelinina et al (2019): Clay- and zeolite-based biogeosorbents: modelling and properties, Építőanyag-JSBCM vol. 71 no. 4 p. 131 https://doi.org/10.14382/epitoanyag-jsbcm.2019.23

[16] Gömze, L. A. - Kulkov, S. N. - Kurovics, E. - Buyakov, A. S. - Buzimov, A. Y. - Grigoriev, M. V. - Kanev, B. I. - Kolmakova, T. V. - Levkov, R. V. - Sitkevich, S. A. (2018): Development ceramic floor tiles with increased 
shear and pressure strengths, Építőanyag-JSBCM vol. 70 no. 1 p. 13 https://doi.org/10.14382/epitoanyag-jsbcm.2018.3

[17] Kurovics, E. - Buzimov, A. Y. - Gömze, L. A. (2016): Influence of raw materials composition on firing shrinkage, porosity, heat conductivity and microstructure of ceramic tiles, IOP Conf. Ser.: Mater. Sci. Eng. Vol. 123, No. 1, p. 012058 https://doi.org/10.1088/1757-899X/123/1/012058

[18] Khare, S. - Sharma, M. - Venkateswarlu, K. (2010): Effect of scandium additions on pressure less sintering of $\mathrm{Al}-\mathrm{TiN}$ metal matrix composites, Építőanyag-JSBCM vol. 62 no. 2 p. 39.

http://dx.doi.org/10.14382/epitoanyag-jsbcm.2010.8

[19] Ershova, N. I. - Kelina, I. Y. (2009): High-temperature wear-resistant materials based on silicon nitride, Építőanyag - JSBCM vol. 61 no. 2 pp. 34-37. http://dx.doi.org/10.14382/epitoanyag-jsbcm.2009.6

[20] Miranda-Hernandez, J. G. - La Torre, D. - Diaz, S. - Rocha-Rangel, E. (2010): Synthesis, microstructural analysis and mechanical properties of alumina-matrix cermets, Építőanyag - JSBCM vol. 61 no. 1 pp.1-5. http://dx.doi.org/10.14382/epitoanyag-jsbcm.2010.1

[21] Apkaryan, A. S. - Kulkov, S. N. - Gömze, L. A. (2014): Foam Glass Ceramics as Composite Granulated Heat-Insulating Material, ÉpítőanyagJSBCM vol. 66 no. 2 pp. 38-42.

http://dx.doi.org/10.14382/epitoanyag-jsbcm.2014.8

[22] Lebedeva, N. N. - Orbukh, V. I. - Eyvazova, G. M. - Darvishov, N. H. - Akhundov, C. G. (2018): Mass transfer of aluminum film from the surface of zeolite on the cathode, Építőanyag-JSBCM vol. 70 no. 4 p. 120 https://doi.org/10.14382/epitoanyag-jsbcm.2018.22

[23] A. Buyakov et al (2019): Structure and mechanical properties of $\mathrm{ZrO} 2-\mathrm{MgO}$ composites with bimodal pore structure, IOP Conf. Ser.: Mater. Sci. Eng. Vol. 613012023 https://doi.org/10.1088/1757-899X/613/1/012023

[24] László A. Gömze et al (2019): Conventional Brick Clays as a Challenge of Materials Science - New Explanation of Drying Sensitivities, IOP Conf. Ser.: Mater. Sci. Eng. Vol. 613012005 https://doi.org/10.1088/1757-899X/613/1/012005

[25] Yu A Rikun et al (2019): Computer Modeling of the Stress-Strain State of the Cervical Spine Segment, IOP Conf. Ser.: Mater. Sci. Eng. Vol. 613 012027 https://doi.org/10.1088/1757-899X/613/1/012027

[26]S .N. Kulkov (2019): Smart Materials Based on a High and Low Temperatures SME-Alloys, IOP Conf. Ser.: Mater. Sci. Eng. Vol. 613 012002 https://doi.org/10.1088/1757-899X/613/1/012002

[27] A Hamza et al (2019): Plasticity of Red Mud and Clay Mixtures, IOP Conf. Ser.: Mater. Sci. Eng. Vol. 613012051 https://doi.org/10.1088/1757-899X/613/1/012051

[28] L. A. Gömze et al (2013) Comparison of material structures and scratch strength of thin films of glass mirrors and automobile windscreens, IOP Conf. Ser.: Mater. Sci. Eng. Vol. 47012023 https://doi.org/10.1088/1757-899X/47/1/012023

[29] S. Kulkov (2013): Formation of Nanostructures in Brittle Materials with Transformations, IOP Conf. Ser.: Mater. Sci. Eng. Vol. 47012042 https://doi.org/10.1088/1757-899X/47/1/012042

[30] A. Y. Buzimov et al (2017): Influence of mechanical activation on the properties of natural zeolites from Tokaj Mountain, IOP Conf. Ser.: Mater. Sci. Eng. Vol. 175012033 https://doi.org/10.1088/1757-899X/175/1/012033

[31]A. Shmakova et al (2017): Crystal chemical characteristics and physical properties of ferrous minerals as the basis for the formation of functional materials, IOP Conf. Ser.: Mater. Sci. Eng. Vol. 175012015 https://doi.org/10.1088/1757-899X/175/1/012015

[32] A. A. Wereszczak - K. Breder - M. K Ferber, - R. J. Bridge - L. Riester T. P Kirkland 1998 (No. ORNL/CP-98893; CONF-980521-). Oak Ridge National Lab., TN (United States). https://doi.org/10.2172/290938

[33] J. F. Scott (2005) New developments on FRAMs: [3D] structures and allperovskite FETs, Materials Science and Engineering: B vol. 120 no. 1-3 p. 6 https://doi.org/10.1016/j.mseb.2005.02.047

[34] D. Zhou, - Y. Chen, - D. Zhang, - H. Liu, - Y. Hu - S. Gong (2004) Fabrication and characterization of the multilayered PTCR ceramic thermistors by slip casting, Sensors and Actuators A: Physical, vol. 116 issue 3 p. 450 https://doi.org/10.1016/j.sna.2004.05.014
[35] Z. G. Zhou, - Z. L. Tang - Z. T. Zhang (2005) mpedance Analysis Study on the Sensing Process of BaTiO3 Based PTC Ceramics in CO Gas, Key Engineering Materials vol. 280 p. 369

https://doi.org/10.4028/www.scientific.net/KEM.280-283.369

[36] A. Jamaluddin et al (2016) Properties of strontium doped barium titanate powder prepared by solid state reaction, J. Phys.: Conf. Ser. Vol. 776 012052_https://doi.org/10.1088/1742-6596/776/1/012052

[37] W.J. Dawson 1988 American Ceramic Society Bulletin, vol. 67 no. 10 p. 1673

[38] S. Komarneni, I. R. Abothu Et A. V. P. Rao (1999) Sol-Gel Processing of Some Electroceramic Powders, J. Sol-Gel Sci. Techno. Vol. 15 p 263 https://doi.org/10.1023/A:1008793126735

[39] G.R. Fox, J.H. Adair and R.E. Newnham (1990) Effects of pH and H2O2 upon coprecipitated $\mathrm{PbTiO} 3$ powders, Journal of Materials Science vol. 25 issue 8 p. 3634 https://doi.org/10.1007/BF00575398

[40] A. Mahapatra, S. Parida, S. Sarangi and T. Badapanda (2015) Dielectric and Ferroelectric Behavior of Bismuth-Doped Barium Titanate Ceramic Prepared by Microwave Sintering, JOM vol. 67 issue 8 p. 1896 https://doi.org/10.1007/s11837-014-1266-7

[41] A. Rani, J. Kolte, S.S. Vadla and P. Gopalan (2016) Structural, electrical, magnetic and magnetoelectric properties of Co-doped $\mathrm{BaTiO} 3$ multiferroic ceramics, Ceramics International, vol. 44 issue 14 p. 16703 https://doi.org/10.1016/j.ceramint.2018.06.098

[42] P.P. Khirade, S.D Birajdar, A.V. Raut and K.M. Jadhav (2016) Effect of $\mathrm{Fe}$ - substitution on phase transformation, optical, electrical and dielectrical properties of $\mathrm{BaTiO} 3$ nanoceramics synthesized by sol-gel auto combustion method, Journal of Electroceramics vol. 37 issue 1-4 p. 110 https://doi.org/10.1007/s10832-016-0044-z

[43] N. Maikhuri, A.K. Panwar and A.K. Jha (2013) Investigation of A- and B-site Fe substituted BaTiO3 ceramics, Journal of Applied Physics vol. 113 17D915 https://doi.org/10.1063/1.4796193

[44] U. Holzwarth and N. Gibson (2011) The Scherrer equation versus the ,Debye-Scherrer equation', Nature Nanotechnology vol. 6 no. 9 p. 534 https://doi.org/10.1038/nnano.2011.145

[45] G.K. Williamson and W.H. Hall (1953) X-ray line broadening from filed aluminium and wolfram, Acta metallurgica vol. 1 issue 1 p. 22 https://doi.org/10.1016/0001-6160(53)90006-6

[46]X. Jin, D. Sun, M. Zhang, Y. Zhu and J. Qian (2009) Investigation on FTIR spectra of barium calcium titanate ceramics, Journal of electroceramics vol. 22 issue 1-3 p. 285 https://doi.org/10.1007/s10832-007-9402-1

[47] R. Ashiri, A. Nemati, M.S Ghamsari, S. Sanjabi and M. Aalipour (2011) A modified method for barium titanate nanoparticles synthesis, Materials Research Bulletin vol. 46 issue 12 p. 2291

https://doi.org/10.1016/j.materresbull.2011.08.055

Ref.:

Tihtih, Mohammed - Limame, Karoum - Ababou, Yahya - Sayouri, Salaheddine - Ibrahim, Jamal-Eldin F. M.: Sol-gel synthesis and structural characterization of $\mathrm{Fe}$ doped barium titanate nanoceramics

Építőanyag - Journal of Silicate Based and Composite Materials, Vol. 71, No. 6 (2019), 190-193. p. https://doi.org/10.14382/epitoanyag-jsbcm.2019.33 